University of Nebraska - Lincoln

DigitalCommons@University of Nebraska - Lincoln

Sociology Department, Faculty Publications

Sociology, Department of

2010

Splitting the Academy: The Emotions of Intersectionality at Work

\author{
Helen A. Moore \\ University of Nebraska-Lincoln, hmoore1@unl.edu \\ Katherine Acosta \\ University of Wisconsin LEAD Center \\ Gary Perry \\ Seattle University \\ Crystal Edwards \\ Nebraska Wesleyan University
}

Follow this and additional works at: https://digitalcommons.unl.edu/sociologyfacpub

Part of the Inequality and Stratification Commons

Moore, Helen A.; Acosta, Katherine; Perry, Gary; and Edwards, Crystal, "Splitting the Academy: The Emotions of Intersectionality at Work" (2010). Sociology Department, Faculty Publications. 103.

https://digitalcommons.unl.edu/sociologyfacpub/103

This Article is brought to you for free and open access by the Sociology, Department of at DigitalCommons@University of Nebraska - Lincoln. It has been accepted for inclusion in Sociology Department, Faculty Publications by an authorized administrator of DigitalCommons@University of Nebraska - Lincoln. 
Published in The Sociological Quarterly 51 (2010), pp. 179-204. Copyright (C) 2010 Midwest

Sociological Society; published by Wiley-Blackwell. Used by permission.

Midwest Sociological Society Presidential Address, March 28, 2008

\title{
Splitting the Academy: \\ The Emotions of Intersectionality at Work
}

\author{
Helen A. Moore \\ University of Nebraska-Lincoln \\ Katherine Acosta \\ University of Wisconsin LEAD Center
}

Gary Perry

Seattle University

Crystal Edwards

Nebraska Wesleyan University

Corresponding author - Helen A. Moore, Department of Sociology, 711 Oldfather Hall,
University of Nebraska-Lincoln, Lincoln, NE 68588-0324; e-mail: $\underline{\text { hmoore1@unl.edu }}$

\begin{abstract}
Using labor market theory, we assess how we have constructed the teaching of required courses on diversity, with the potential splitting of the academy into distinctive labor markets. In-depth interviews with instructors of color and nonminorities who teach required diversity-education courses at a predominately white university are qualitatively assessed and describe the differences in the emotional labor attached to this segmented academic market. We identify specific dimensions of diversity teaching that attach to the job conditions of secondary labor markets, including the distortion of work loads and evidence of differential barriers in the emotional labor attached. These labor market conditions may structurally limit opportunities for career survival and advancement of minority and female instructors.
\end{abstract}

\section{Splitting the Academy}

Education in the United States has been subject to countervailing pressures between those policy makers committed to maintaining the status quo of racial, gendered, and class inequality, and those seeking social justice. This spring, Ward Connerly targeted five states, including Nebraska, for ballot initiatives to curtail affirmative action in higher education (http://www.acri.org). As sociologists, we are particularly attuned to these political pressures through reflections on our own scholarship, teaching, campus policies, and our everyday experiences within the academy. Retention of minority and female faculty and graduate students has gradually captured mainstream disciplinary discussions. Yet 
we lack substantive knowledge and thick discussions of how our own academic workplace is affected by the day-to-day work settings we create through our responses to disciplinary and academic macro-processes. This article examines the problem of a stratified higher educational system at predominately white institutions that reflect white EuroAmerican and male privileges. We study how these privileges extend into the dynamics of diversity/multicultural curricula that are now required elements of the undergraduate program on a majority of these campuses, and the potential impact of these dynamics on diverse instructors in the academic labor market. We are particularly interested in how teaching about diversity may potentially split the academy into distinctive labor markets and the differences in the emotional labor attached to these distinctive academic markets (Bellas 1994, 1999; Harlow 2003).

Both the ASA and APA reports (APA 2004; Spalter Roth and Erskine 2007) point to the lack of gender and ethnic/racial parity in tenure status nationally and conclude that ethnic minority and female faculty are more likely to leave academia and to be more dissatisfied than their white male counterparts (see also Gregory 2001 and Harlow 2003). The critical mass of white men at the full professor level in disciplines and in academic administration likely enhances the work environment and tenure outcomes for white men, but may increase feelings of isolation and lack of social support for female and ethnic minority faculty (APA 2004).

We have several decades of scholarly tradition in researching the academic workplace at the macro-level that reveals its intense stratification by race, class, gender, and sexuality (Blau 1973; Rosenfeld 1981; Menges and Exum 1983; Blackwell 1988; Bellas, Neal Ritchey, and Parmer 2001; Browne and Misra 2003; Harlow 2003; Karabel 2004; Renzulli, Grant, and Kathuria 2006).When defending social justice hiring and curricula against political backlash at the state or campus level, we cannot ignore the uneven social and historical processes of increased demands for diverse faculty, multicultural curricula and scholarship, and the trickling pipeline of instructors who bring their identities into the classroom. We conducted research over the past few years on the experiences of teaching courses on race/ethnicity and our studies are both strengthened and hindered by the experiences and social roles we occupy and by the lack of theories to guide us. We each taught diversity-education courses at the University of Nebraska-Lincoln and we each bring lived experiences and social standpoints that are influenced by our different racial-ethnic, gender, age, sexual, political identities, and academic positions, once ranging from graduate instructors to a full professor.

Today we are a research and pedagogical faculty across a range of institutions, each still affected by the structures of social inequality in the academy. In our work, we conceptualize gendered and racialized emotional labor as a social structure within higher education, and analyze how higher education practices are embedded at individual, interactional, organizational, and institutional dimensions (Risman 2004). Like Risman, we conduct this research in order to transform our campuses, our discipline and higher education.

The American Association of Colleges and Universities documents that 63 percent of colleges and universities report having in place, or developing, a diversity education component in their undergraduate curriculum (AACU 2000). Of those with a diversity com- 
ponent, the majority of campuses (68 percent) require their students to take at least Intersectionality in the Academy Helen A. Moore et al. one course from a list of approved diversity-education courses. This success at integrating multicultural or diversity education into the academic curriculum marks a significant higher education milestone.

Decades ago, Bill Exum cautioned that the minority faculty will find themselves confronting a particular dilemma: "at precisely the point in history when political pressures for increased hiring of minority faculty have resulted in some positive response from higher education, economic constraints and the demographic characteristics of higher education have combined to produce fewer available jobs for (tenured) faculty in general and fewer 'good' faculty positions" (1983:392).Antonio (2002) lists the following factors that stifle efforts at enhancing minority representation: a small and decreasing pool of minority Ph.D.s, disproportionate tenure rates and rates of pretenure departure, and the persistence of racist perceptions on institutional and individual levels that restrict access and impede the professional progress of faculty of color.

The diversity-education classroom is a particular site of meaning for instructors of color at all academic ranks, from graduate teaching assistants to Full Professors (Bell, Morrow, and Tatsogluol 1999; Turner 2002; Perry et al. 2006). In this article, we add to Exum's discussion by assessing how labor market theories enhance our understanding of how we have split our own academic endeavors over the faultline of diversity curricula. Large-scale political resistance, micro-level student resistance in the classroom, and the uneven assignment of tasks to political minority groups within organizations to carry out diversity education on campuses complicates our work. To guide this discussion, we will draw on Patricia Hill Collins's (1990) richly developed frameworks of intersectionality and extend gendered organizational frameworks (Acker 2006; Britton and Logan 2008). Scholarship in race/class/gender and sexuality recognizes that these dimensions do not operate independently of one another, and forms of oppression even in the academy interrelate and reflect the "intersections" of multiple forms of discrimination (Risman 2004). Hill Collins (1990) argues that discrete forms of oppression actually shape, and are shaped by, one another.

To better understand oppressed groups working in the academy, we investigate the particular structure of diversity classrooms at a Research I institution. The academic pipelines and general education requirements created on campuses are influenced at many levels, including the social processes in the larger academy and the social representations within our classrooms. Baca Zinn and Thornton Dill's (1994) Matrix of Domination emphasizes that sociologists' lives are indeed affected by the multiple hierarchies in which we are located. In their work on difference and domination, they ask the key stratification questions that lead us back to labor market theories: who benefits from these academic arrangements? Cui bono? Whose interests are met by the ways departments assign their instructors to diversity courses? Have we hitched diversity curricula and their instructors to a devalued secondary labor market within the academy? Do modern forms of racism and sexism in the academy stratify our academic privileges and embed these in the emotional labor/burden of diversity teaching?

Empirical evidence of stratified academic privilege abounds. Browne and Misra (2003) note that in general, the salaried academics at the bottom of the social hierarchy in terms 
of race or gender are more likely to receive lower wages, to be subjected to stereotypes and discriminated against, or be hired for exploitive domestic positions. Karabel's (2004) history of the "big three" Ivy League campuses reminds us that inclusion and exclusion by race/ethnicity, religion, and gender ebbs and flows with the self-interests of dominant groups of white males.

This "locational" or positionality approach reflects different and changing racial and gender systems and their intersection with other societal stratification systems (Hill Collins 1990) and labor markets. Rather than identifying the separate impact of race, gender, and class on individuals' lives, feminist antiracist theory stresses the need to develop understandings of how these forms of stratification intersect and overlap (Bell et al. 1999). As Acker summarized in her early work on gendered organizations, "a woman who is Black, Spanish speaking and a doctor, does not experience herself in disjointed segments of gender, race, ethnicity, and class; rather, all these elements are produced and reproduced within the same everyday experiencing of her life" (1999:51). Likewise, a female graduate teaching assistant of color assigned to teach a course on race relations to general education students is experiencing her identities within a "peculiar" labor market within the academy.

The APA (2004) survival guide concludes that women and ethnic minorities do not receive promotion and tenure at rates comparable to those of white men:

. . . NOT because women and ethnic minorities are less deserving, work less hard to achieve tenure, or make contributions of lower worth or significance than their White male colleagues. Success in the academic arena is governed to a large extent by adherence to a set of explicit and implicit rules and priorities that women and ethnic minorities have had little role in shaping and sometimes find alienating and oppressive.

These academic dilemmas occur in organizational settings. Acker moved gender from the realm of the individual to that of the structural (Britton and Logan 2008) by focusing on organizations wherein "advantage and disadvantage, exploitation and control, action and emotion meaning and identity are patterned" (Acker 1990:146). Acker conceptualizes the concept of "inequality regimes" as fluid, changing and "loosely interrelated practices, processes, actions and meanings that result in and maintain class, gender, and racial inequalities within particular organizations" (2006:43). Britton and Logan see a need to further expand and specify Acker's "framework" of organizational intersectionality to demonstrate how inequalities become part of an organizational logic so that over time they come to "seem only natural" (2008:117).

To better understand these gendered and racialized structures of work, we turn to the concepts and theories of labor markets (dual, segmented, internal, and split market theories) and apply these to campus-based structures and processes of diversity education. We then discuss the diversity-education classroom as one site wherein social conflicts may take on emotional meaning for instructors of color and female instructors at all academic ranks (Turner 2002; Perry et al. 2008).

In this article we weave analyses of emotional labor into our framework of the racialized and gendered nature of secondary, devalued academic labor markets (Hochschild 1979; Steinberg and Figart 1999; Mirchandi 2003). Within this context of labor market the- 
ories, we reframe the intersectionality of emotional labor in academic organizations at the pivotal point of the required diversity classroom. We argue that this is an organizational factor that operates across campuses and generates an overarching dynamic within and between distinct academic labor markets on individual campuses. Labor market theory allows us to assess whether these diversity classrooms might work at cross-purposes with national disciplinary efforts to support more diverse faculty, their scholarship, and pedagogy. Our goal is to show how labor market theories amplify antiracist and feminist critiques of academic pipelines and processes and we hope to suggest organizational policies that may buffer against our unconscious development of devalued secondary academic markets on our own campuses.

\section{Dual and Internal Labor Market Theories}

The concept of the dual labor market (Doeringer and Piore 1971; Gordon, Edwards, and Reich 1982) first frames our understanding of the interplay among labor markets and the academy. Those positions and people associated with a core or primary markets comprise a distinctive set of privileges and rewards from those in the secondary market. Roemer and Schnitz (1982) note that according to dual labor market theory, inequality is institutionalized by a structural dichotomy within the labor market that cannot be removed solely by increasing or redistributing human capital.

An economic dualism systematically stratifies the economy into a primary and secondary labor market, each characterized by different working conditions, different promotional opportunities, and different wage structures. In general, the primary labor market is characterized by high wages, good working conditions, employment stability and job security, due process in the administration of work rules, and opportunities for advancement. This contrasts with the secondary market that features low wages, poor working conditions, considerable variability in employment, harsh and often arbitrary evaluation, and little opportunity to advance. (P. 582)

They argue the most significant distinction between the two markets is the discrepancy in job stability and security. In the secondary labor market, workers face substantial job instability and employment is not clearly connected to core or primary occupational ladders. Evaluations are often vague and arbitrarily rewarded by privileged workers.

The idea of the academic labor market having distinctive and unequal structural dimensions is not new (Blau 1973; McBrier 2003). Opportunities are differentially distributed and emerge under conditions in which effort or reward is intensified, control is decentered, and employment is destabilized (Smith 1997). Empirically, Bellas and others have studied academic markets focused on salaries, finding that rewards are more similar for faculty within disciplines than faculty from different disciplines (Bellas 1994, 1999). These academic market differences are conceptualized as parallel to business norms through a calculus of student credit hours, competitive reward structures and the metric of grant dollars (AAUP 2004; Kulis 2003). These processes stabilize a privileged academic 
market: faculty in primary academic markets are higher paid (Renzulli et al. 2006), have more access to governance and intangible resources: greater control over teaching assignments, graduate student assistants, tenure-line positions and grant resources (Blau 1973; Menges and Exum 1983).

Some researchers specify the duality of academic labor by assessing the permeability of academic internal markets (moving from nontenure to tenure track jobs) and describing the weakening of work conditions for nontenured academics. Rosenblum and Rosenblum (1996:430) describe a primary or core academic labor market composed of secure, career-linked work contrasted to transitory or unstable work in secondary academic markets. "These represent very major structural differences between 'good' and 'bad' jobs" (1996:430). Considering only gender, they demonstrate differential recruitment of men and women into these two markets, with women more frequently entering universities via the low retention, secondary external markets. Think of this as the difference between arriving at your university as an adjunct instructor waiting for a line to "convert" to a tenure track line, or being recruited at the tenured full professor level. These are distinctive queues into distinctive academic markets (Reskin and Roos 1991). "Research documents disproportionate recruitment of minorities to academic labor markets and lasting negative effects including later disadvantages in the academy and the 'disorderliness' of their subsequent careers" (Rosenblum and Rosenblum 1996:439).

What we do argue is that the (secondary) external labor market must be a recognized part of the recruitment processes of contemporary universities, and one in which few, if any, procedures or procedural safeguards exist with respect to entry into the (primary) internal labor market.... (P. 435)

Menges and Exum (1983) called for caution when creating academic niches such as "opportunity hires" and joint appointments with Ethnic Studies and Women's Studies programs. Today, we extend this caution to the required diversity course. In interviews with 47 instructors of these courses across 14 disciplinary programs (cf. Perry et al. 2008 for methodological details), we found strong suggestions that the required diversity courses do construct a distinctive niche of responsibility and burden in the academy (pseudonyms are applied):

I don't want to use the analogy "dumping" . . . but it's a difficult course and people are scared (Joyce, an African American tenured Professor). José (a tenured Latino faculty member) joked that he was offered the diversity course because he is a minority. I laugh about that ... I'm almost certain that if I don't want to teach that they wouldn't force me. [emphasis added]

Roemer and Schnitz (1982) argue for the fit (not perfect) between noncore academic positions (even tenured positions) and secondary labor markets. Destabilized work is a key structural characteristic when jobs are contingent on factors beyond employee control (i.e., student enrollment and evaluations, public legislation on hiring and curricula, or "tastes" of private donors in funding niche programs). They highlight the degraded working conditions that characterize noncore positions, especially when secondary mar- 
ket instructors are routinely assigned instructional tasks that most professors with clout avoid: large classes, multiple sections of the same course, and introductory or remedial courses (p. 522). These conditions extend to the diversity classroom both in challenges to instructor's authority and credibility (Harlow 2003; Perry et al. 2006) and in the emotional drain of "the weight of representing the entire race" (Harlow 2003:362). As argued by Joyce in our interviews:

... Are you going to want to take on the course that is going to emotionally cost this much? And knowing that, why in the world would we give people who are green behind the ears (graduate teaching instructors) that course and then say we value that course? That's inconsistent.

Roemer and Schnitz further argue that dual academic working conditions can be measured in two ways: (1) how much time a faculty member's assignments leave available for research and (2) how closely instructional assignments correspond to research interests. If those holding nontenure track positions are assigned only the most onerous teaching responsibilities and if they are given no opportunity to teach advanced courses in their specialties, or work with advanced doctoral students, then their working conditions fail to promote their professional growth as scholars (Roemer and Schnitz 1982).

As one minority instructor in our interviews posed: "I don't mind teaching diversity, but I would prefer my areas of specialty." Similarly, Bobby (an African American instructor) indicated that "although I'm not upset that I'm teaching diversity . . . it was not my choice... [It] was more of an assignment from the department."

Jerry Jacobs's (2004) research on the faculty time divide reminds us that the segmentation of academic life into an overworked core and a marginalized periphery perpetuates academic inequality. Core and noncore academic positions differ considerably on measures of time available for research and time demanded for teaching and service. When teaching loads, committee assignments, and merit increases are strongly skewed in favor of core faculty, then those in secondary positions may perceive that they are the recipients of harsh and arbitrary treatment as well. Academic jobs fit the secondary labor market because they explicitly or covertly limit opportunity for advancement.

Tenure track jobs can be limited as meaningfully "by the differential working conditions attached" to secondary academic niches (p. 530). Tenure track faculty and graduate teaching assistants who are routinely assigned disproportionately to the "most onerous teaching responsibilities" are part of a noncore market and constitute a horizontal axis of instructor positionality. As Harlow notes: teaching diversity courses can be particularly draining "for young faculty members who may spend hours poring over lectures so as not to be anything less than perfect or totally prepared" (2003:362).

\section{Splitting the Academic Market}

Most discussions of dual labor markets and academic markets are limited to gender and black/white differences (Kalleberg and Sorensen 1998). We need an expanded labor market analysis informed by a wider assessment of colonized racial/ethnic mi- 
nority groups (cf. Blauner 1972) and the institutional roles created through economic, legal and educational control by dominant groups in the academy (Baca Zinn and Thornton Dill 1996). Before a Ph.D. is earned, students queue up by race, ethnicity, gender, and social class (Reskin and Roos 1991) within gendered and racialized organizations (Acker 2006). We now turn to split labor market and internal labor market analyses to better understand these patterns of intersectionality in the broader academic market.

What does split labor market theory offer? Bonacich (1972) identified a split labor market as one in which employment practices create a large differential in the material conditions and dynamics of labor for the same occupation. Key to her theory is the premise that oppressive employment practices may be instigated by employers (those seeking larger profits by displacing more privileged and more highly paid labor with cheaper labor) or by privileged workers (seeking to exclude cheap labor from undercutting their privileges and benefits). Her analysis of racially split markets examined historical developments that led employers to seek cheaper labor elsewhere and left pockets of disadvantaged workers. Other analyses reaffirm that blacks and Latinos experience destabilized jobs and degraded working conditions as dominant groups of workers exclude racial minorities through structured privileges and insist on segregated work facilities (Baron 1975; Barrera 1979).

Sociologists also demarcate labor markets that are split or segmented along vertical axes to identify internal labor markets and assess the demography of workers within occupations. Segmentation by race and gender is complicated by differentiations in tasks, power, and wages (Kulis and Shaw 1996, 1997; Acker 1999, 2006; Renzulli et al. 2006). Menges and Exum (1983) asserted the racialized academic market of pipeline training and hiring (especially in joint appointments), as well as distorted faculty evaluations that reduce retention. These academic splits are exacerbated when significant proportions of minority faculty hold joint appointments between a traditional department and an ethnic studies program or department (NB, some faculty of color hold triple appointments that include women's and gender studies-perhaps a form of triple jeopardy). Exum (1983) concludes that minority faculty members often are hired not only because of who they are, but also because they are presumed to have expertise in new areas (ethnic studies), and are often placed in these joint appointment settings to their disadvantage. "The individual faculty member must manage two 'masters' and two sets of expectations. Not only is time for research further fragmented, but each master may see its work as pre-eminent and evaluate performance accordingly" (Exum 1983:395).

This split adheres within the teaching and service domains as well, when "joint" Ethnic Studies program administrators seek to stabilize their curricula, and departments assign faculty members nonrandomly to teach courses on racial diversity or to teach in lower division courses that meet diversity requirements and generate large enrollments. These processes create narrowed pedagogical niches and potentially differential time commitments for the "same" three credit hours course calculus. Service work may also be devalued and carry burdens that are invisible to academic colleagues with less restricted pedagogical choices, and privileges of assignments and scheduling that better "fit" core academic norms they create. 
At the same time, minority faculty members are often given more chances to fill service responsibilities than their white peers - and they are expected to take them (Aguirre 2000). "Minority faculty are especially vulnerable to conflicting expectations from the various 'audiences' or constituencies they must satisfy: minority students, white students, faculty peers, departments, administrators, and trustees" (Exum 1983:395). "Many women faculty of color are called on to advise students of color and others studying in similar fields. Because of their scarcity, faculty women of color can face great out-of-class instructional loads" (Turner 2002:86). They must balance teaching, research, and service to the institution, knowing that there are pressures to perform in each area, although rewards are not equal.

If service addresses social justice issues "it can be a source of pride and validation for many minority faculty. It gives them much needed connection with communities of color within and outside of the academy as a whole, which can translate into supportive networks for the individual providing the service" (Turner 2002:84). "Inescapably, whenever a minority person is hired in a faculty position, he or she is a role model, expected to be an advisor, a counselor, an advocate, and a sympathetic listener for minority students" (Blackwell 1988:424).

The racialized and gendered nature of internal academic markets exists in unequal assignments across teaching and service, differential research productivity, the role of family responsibilities, and the androcentric tenure clock (Paludi 1990; McBrier 2003). Bird, Litt, and Wang (2004) add to this list the undervalued labor of "institutional housekeeping." They examine the process and structure of data collection, analysis, and invisible policy labor focused on campus diversity. These tasks are primarily assigned to women and faculty of color and "their" commissions:

The underlying logic of the reward structure for work within universities assumes a gendered division of labor. First, work within the university is divided into core and support activities. . . Support or "service" activities . . . considered less prestigious, include committee work, advising, and civic contributions. Although all these activities are essential, not all are equally valued. Men, especially Euro-Anglo men, insofar as they are less involved in support activities, particularly those involving institutional housekeeping, have more time to pursue higher status, higher paying core activities. Women and people of color, insofar as they are more involved in support activities, especially institutional housekeeping, have less time to pursue higher status, higher paying core activities. (Bird et al. 2004:199)

These internal and vertical arrangements are neither color blind nor gender neutral (Acker 2006). Consider how the following academic tasks are racialized and gendered: campus child care, interdisciplinary work with women's/gender/racial/ethnic studies programs, academic observances to honor minority group member contributions, committees of women's/gender and ethnic studies programs, diversity recruitment; advising minority students and student groups, consulting on grants for research on minority populations, tenure and promotion rules that reward impartial discovery over community advocacy or teaching, and peer review by peers from segmented disciplines (Aguirre 2000; Trower 2002; Turner and Meyers 2000; Turner 2002). 
Many review problems for minority faculty stem from the fact that traditional conceptions of merit and traditional review practices continue to be dominant on most campuses, even though criteria and the specific weight given them are often unclear (Gaston et al. 1975; Lewis 1975), and even though minority faculty, like female faculty, often face tasks not easily or appropriately evaluated by traditional measures. These suggest the necessity for additional or alternative conceptions of merit in order to produce equitable evaluation. (Exum 1983:395)

Exum argues that minority academics often challenge prevailing conceptions of scholarship in terms of content, theoretical paradigms, underlying philosophies, and methodology. Their work on new or unfamiliar knowledge is often developed through "unconventional paradigms" (1983:395) or methodologies. We might assume that this creates parallel problems in evaluating how new scholarship and new pedagogy reverberates within the classrooms in which this scholarship is taught and learned. Merging elements of dual, split and internal labor market provides a more dynamic explanation for how the work of teaching diversity courses potentially splits the academy as a labor market, even while assessing individual work organizations. Much of this work is invisible to dominant departments and administrators; the national calculus equates one undergraduate classroom with another. "Attempts to achieve racial equality in society are mediated through institutional choices and characteristics to produce results which continue to disadvantage racial minorities, both collectively and individually" (Exum 1983:383). The structure of these market characteristics should be closely examined for key dimensions: (1) distorted, devalued work loads in teaching (evidence of "dumping"); (2) structurally limited opportunities for advancement or access to core scholarship development strategies of the dominant group (evidence of unequal privileges and burdens); and (3) the connections of these secondary market characteristics to the retention of graduate teaching assistants (the new pipeline) and faculty members. In the following illustrations, we focus on the first two elements of split academic markets and unequal burdens.

\section{Demographics and Diversity Education}

The expansion of diversity requirements occurs at a time when the academic labor market is undergoing significant structural changes with regards to academic jobs, race, and gender. Over the past 30 years, university administrators have shifted a large proportion of teaching duties away from regular faculty to part-time and adjunct faculty (Ivey 2005) and to graduate teaching assistants (Pratt 1997). The mass use of contingent instructors and increased use of joint appointment faculty has brought about some problems: equity among academic colleagues, integrity of faculty work, academic freedom, etc. (Ivey 2005:5). Sixty-five percent of the higher education faculty members are contingent faculty members (Ivey 2005) and the majority of new hires in higher education are not on tenure track.

Exum exhorted us to pay attention to shifting academic demographics, and the latent effects of these, bringing us to the site of the diversity classroom itself. Kulis and Shaw's 
(1996) research into academic labor markets demonstrates that racial diversity among postsecondary employees occurs unevenly across institutions. These patterns are shaped by constraints of the labor market (increasing joint appointments, adjunct, and graduate teaching assistant positions), by external administrative activities (General Education requirements), and by internal structural arrangements (department teaching assignments). Kulis and Shaw predict "The roots of racial inequalities in employment [in higher education] may be diverging as different dynamics fashion racial composition at the top and bottom of the postsecondary job hierarchy" (p. 586).

The broader academic labor market contributes to contradictory experiences when connected to diversity course requirements and student credit hour counts, diversity hiring initiatives, and affirmative action in student admissions. How then have diversity tasks been constructed around race and gender in the academy? When are diversity classroom assignments linked to classroom emotional responses, evaluations of instructors, scholarship development, and retention at predominately white campuses that "do" diversity work?

Our current study is part of a larger project in which participant-instructors were purposefully selected from an original list of all 66 instructors, of all races and ethnicities, who taught at least one required diversity-education undergraduate course over a twoyear period on a Research I campus. These courses were compiled using the University of Nebraska-Lincoln Bulletin to specify three-hour credit courses that satisfy the requirement in diversity education (see Perry et al. 2008).We recruited instructors by mail, telephone, or in person, and drew participants from a wide range of program areas, including Communication Studies, Curriculum and Instruction, Textiles/ Clothing, Family and Consumer Sciences, Economics, English, History, Political Science, Psychology, Anthropology, Sociology, and Ethnic and Women's Studies. We successfully completed and transcribed 47 interviews (a 71-percent response rate). ${ }^{1}$

To assess the employment distortions in diversity education on our campus, Table 1 summarizes self-reported demographic characteristics for the overall group of 47 participant-instructors. Almost half of all diversity course instruction is provided by adjunct or graduate teaching assistants who serve as the instructor of record. Almost half of the graduate instructors in these diversity courses are graduate students of color (47 percent). Among the general student population of U.S. residents on the University of Nebraska-Lincoln campus, only 6 percent of all graduate students are black, Native Amer-

Table 1a. Academic Status of Diversity Instructors

\begin{tabular}{lcc}
\hline Status & Number & Percentage \\
\hline Graduate teaching assistants & 21 & 45 \\
Adjunct faculty & 1 & 2 \\
Assistant professors & 8 & 17 \\
Associate professors & 4 & 9 \\
Full professors & 13 & 27 \\
Total & 47 & 100 \\
\hline
\end{tabular}


Table 1b. Instructor Academic Rank by Minority*/Nonminority Status $(\mathrm{n}=47)$

\begin{tabular}{lccccc}
\hline & \multicolumn{2}{c}{ Male } & & \multicolumn{2}{c}{ Female } \\
\cline { 2 - 3 } \cline { 5 - 6 } Status & Minority & Nonminority & & Minority & Nonminority \\
\hline Graduate teaching assistant & 6 & 1 & & 2 & 8 \\
Adjunct faculty & 1 & 0 & & 3 & 0 \\
Assistant professor & 5 & 0 & & 4 & 0 \\
Associate professor & 3 & 0 & & 1 & 0 \\
Full professors & 4 & 2 & & 0 & 7 \\
Total & 19 & 3 & & 10 & 15 \\
\hline
\end{tabular}

* Includes those who self-identified as Puerto Rican, Cuban, Chicano, and Mexican American; Black/African American, Native American. No diversity instructors identified as Asian.

ican or Hispanic/Latino (230 students out of 3,783 Graduate and Professional Program enrollments).As in most literature, we define an instructor of color as one who self-reported racial-ethnic identities other than "non-Hispanic" or "Euro-American" or white or Caucasian.

Our instructors of color identified as Hispanic/Latino, African American, American Indian, and African, but we found no self-identified Asian instructors in the required diversity course listing (NB Asians are the largest nonwhite group on campus, representing 7 percent of the 1,452 faculty). Among our total group of instructors, nine identified as gay or lesbian, and three of these simultaneously identified as instructors of color. Given these complex intersections of identity in the diversity classroom, we use the general term "participant-instructors" for all of our respondents of any academic rank.

For tenure track and tenured faculty at the Assistant and Associate level, we found that among nonminority faculty, no male or female faculty members were represented in our two-year sample from a campus-wide pool of 197 Assistant Professors and 354 Associate Professors. Twelve minority male and female faculty members from these two ranks were teaching required diversity courses (from a total of 39 minority faculty at these ranks). On our campus, we hold a strong norm of "protecting" faculty who are pre-tenure or not fully promoted.

Almost one-fourth of the instructors of diversity courses are Full Professors; however, this included only two white-European males ( 0.4 percent of the 436 white male Full Professors on campus). Of the 86 white female Full Professors, more than 8 percent (seven total) were involved in diversity education. Strikingly, of a total of 13 Full Professors of color (Latino, African/African American, American Indian), we find that 30.1 percent of these professors are involved in required diversity education courses (note that we have no diversity requirements at the Graduate College where Full Professors devote more substantial amounts of their teaching time than lower ranked instructors).

Diversity instruction now confronts us as a "peculiar" niche within the academic labor market. Gallos, Jean Ramsey, and Associates (1997) describe the role of diversity educators as full of dilemmas and paradoxes of devaluation. "We are often seen as troublemak- 
ers, radicals, people who cannot fit or thrive in the mainstream. Rarely are we seen as experts in an important area. ... Until I began focusing more directly on issues of diversity, I was never seen in a negative light. Now I've become suspect. My research is suddenly seen as less valuable and less sound" (p. 141).

This diversity work is challenging for all instructors, but it is documented as especially problematic for graduate instructors and instructors of color. In national studies, majorities of graduate instructors report that they receive minimal training, supervision, and feedback for teaching generally (Anderson and Swazey 1998; Turner and Meyers 2000). Diversity instruction may impose additional burdens on minority graduate instructors, who often report having their credibility and authority challenged in the classroom on a regular basis (Jimoh and Johnson 2002; Harlow 2003; Perry et al. 2009).

For faculty instructors, Vargas $(1999,2002)$ and Turner $(2000)$ argue that many problems are rooted in the fact that as women of color, they are teaching in predominantly white college classrooms. Vargas uses the term "white classroom" to refer to a classroom dominated by "non-Latino White/Caucasian persons, their culture, and their institutions" (2002:5). Male faculty of color also face problems when administrators fund new positions for their new campus diversity requirements. One male Latino instructor stated that his ethnic studies program lacks funding and is informally denied legitimacy as an academic program of scholarship. He did not think the university made the reasons behind the diversity courses clear. "I think the university is well-intentioned, but unfortunately, there hasn't been to my knowledge an across-the-board conversation or framework establishing how these [diversity] courses will [fit into the university's mission]," he said. He is noted as recently removing himself from consideration for tenure on that campus (McCluskey 2004).

\section{Emotional Labor in Service to Diversity}

When black and white faculty members teach, they function in disparate realities. White professors operate in a social space where whiteness is crediting and privileged, but is invisible and thus is taken for granted; African American professors function in a space where blackness is discrediting and devalued. (Harlow 2003:362)

Gregory cites the African proverb "She who learns must also teach" to echo the cultural importance of black faculty women's efforts to share their knowledge with others, despite opposition, or challenges. Researchers emphasize that faculty of color experience daily cultural assaults on their identity stemming from historical stereotypes among students and academic demands (Aguirre 2000; Turner 2000). Their exclusion from the academic mainstream has negative effects by "contextually entrapping women and minorities into roles in which they are perceived, and sometimes perceive themselves, as tokens, curiosities, or anomalies in the academic workplace" (Gregory 2001:126). Minority academics of all ranks often regard the academy as a place that principally fosters the needs and interests of white males and white students. 
Against these macro- and micro-diversity politics, we focus on the required diversity course and some dimensions of the emotional labor attached to this work. Hochschild (1979) defines emotional labor as emotion management performed as part of one's paid employment and included college and university teachers on her list of 44 census occupations that involve significant amounts of emotional labor (Hochschild 1983).Her research illuminates those "feeling rules," or social conventions governing how individuals should feel in a given situation with guidelines for how we label, assess, manage, and express emotions (Hochschild 1979). The dyadic interactions between workers and patrons forms ". . . labor-intensive work; it is skilled, effort-intensive, and productive labor. It creates value, affects productivity, and generates profit. It is why frontline service workers and paraprofessionals have been referred to ... as the 'emotional proletariat' " (Steinberg and Figart 1999:9). Steinberg and Figart argue that performing emotional labor, especially authentic caring relationships, is not necessarily a requirement of all jobs (1999:12). Other studies examine the impact of emotional labor on job satisfaction and on negative psychological outcomes (cf. Steinberg and Figart 1999 for a thorough review).

The gendered nature of academic teaching and emotion work has been highlighted before by Bellas and other researchers in women's studies and education scholarship.

... professors' work activities are gendered, and so, too, is the academic reward structure. Teaching and service are most closely aligned with social prescriptions of appropriate feminine activities, and, on average, women spend more time in these activities than men. . . Teaching and service clearly involve substantial amounts of emotional labor-labor that is generally not viewed as involving valuable skills and is consequently poorly rewarded. (Bellas 1994:97)

Mirchandi's (2003) research on emotion work concludes that little or no attention has been paid to its racialized dimensions:

... the exclusion of racial analyses is symptomatic of a unidimensional understanding of gender based on universalized conceptions of "men" and "women" underlying many studies of emotion work. Contemporary debates on emotion work normalize whiteness in two ways: first, through the reliance on racially homogeneous samples in empirical studies, and second, through the assumption that workers are, by default, white. (Mirchandi 2003:724)

Harlow (2003) focused on black and white professors' strategies for managing their own emotions at a predominately white institution. She finds that the emotion management required of black professors is more extensive because they experience challenges to their credibility and authority in the classroom that whites do not. The black professors in her study described these myriad expectations as emotionally draining (Harlow 2003:362). Turner (2002) also summarizes the teaching experiences of faculty of color as generally bittersweet. "The interlocking effects of gender and race compound the pressures of the workplace environment for faculty women of color. They perceive that being both minority and female hampers their success as faculty members" (Turner 2002:97). A quarter century ago, Kolodny (1980) situated feminist scholarship and pedagogy within 
work that is "more than a set of disconnected, unrealized private emotions ... what had once been felt as personal insecurity could now be viewed collectively as structural inconsistency within the very disciplines we studied." She describes emotion work as potentially liberatory, promising and a powerful impulse.

The emotional responses of minority instructors to their academic positionality provide important opportunities to reflect on the academic work place that sociologists help shape. Sleeter (1996) and Sleeter and Stillman (2005) recognize that multicultural and diversity education programs have roots as a social movement, but most nonminority academics do not think of this work in terms of collective action aimed toward institutional change (Harlow 2003). Our assessments of labor market theories, academic praxis and privilege, and gendered and racialized structures enable us to interrogate the effects of curricular requirements and our leaking pipelines of diverse instructors. The following discussion of gendered and racialized emotions in response to diversity courses is intended to illustrate potential policy arenas for our own work places. Having illustrated the overall disproportionate burden carried by diversity instructors of color, we next suggest the differentiated emotional content of that burden.

\section{Splitting the Emotional Labor of the Academy: A Word (or Words) about Diversity Pedagogies}

As described earlier, we conducted interviews with 47 instructors of required diversity courses. We selected in-depth interviews as the format best suited to a population whose voices are often omitted or distorted in more positivistic research inquiry (Reinharz 1992). More detailed discussions of our overall coding methods and the larger project on teaching diversity education is reported elsewhere (Bass et al. 2008; Perry et al. 2008).

To illustrate the distorted emotional labor in teaching diversity courses, we focus on the elicited wording of 26 participant-instructors who were interviewed during the second half of our data collection. To minimize the inaccuracies in both our coding and interpretation of our qualitative interviews, we routinely met as a group to discuss our understanding of the data (cf.Creswell 1998 on processes of peer review and debriefing). About halfway through conducting and analyzing our interviews, we discussed emergent themes and constructed a new set of questions for more direct comparisons of emotional responses to the diversity classroom. We asked participant-instructors in later interviews to "please list five words you would use to identify your emotions involved in teaching a diversity-education course." These 26 later interviews included seven men of color (including two Latino/Hispanic, three African American, and two Native American); seven women of color (three Latina/Chicana, four African American, and one Native American); and twelve white Euro-American instructors (including two males and ten females).We thematically coded the words provided by them to identify modal categories and clusters by face validity strategies (such as including "frustrated" and "exasperated" in the same category; or contrast categories of "joy," "delight," and "bliss").

To understand the linguistic map constructed by these words, we first contrasted the density of the list of words called on by our instructors by presenting an average word count by race and gender (see Table 2). Then we compared the thematic constructions of 
Table 2. Ranked Clusters of Emotional Reflections on Diversity Education (Number of Words) ( $\mathrm{n}=$ 26)

\begin{tabular}{|c|c|c|c|c|}
\hline & 1 st & 2nd & $3 \mathrm{rd}$ & 4th \\
\hline \multicolumn{5}{|l|}{ Females } \\
\hline \multicolumn{5}{|l|}{ Race/Ethnicity } \\
\hline $\begin{array}{c}\text { European American } \\
\mathrm{n}=10 \\
(\mathrm{X}=4.2)\end{array}$ & $\begin{array}{l}\text { Frustrated/ } \\
\text { Exasperated (6) }\end{array}$ & $\begin{array}{l}\text { Joy/Delight/ } \\
\text { Bliss (6) }\end{array}$ & $\begin{array}{l}\text { Anxiety/Stress/ } \\
\text { Insecurity (4) }\end{array}$ & $\begin{array}{l}\text { Fear/Hurt/ } \\
\text { Intimidated (3) }\end{array}$ \\
\hline $\begin{array}{l}\text { WOC } \\
\qquad \begin{array}{l}n=7 \\
(X=4.63)\end{array}\end{array}$ & $\begin{array}{l}\text { Anger/Rage/ } \\
\text { Resentment (7) }\end{array}$ & $\begin{array}{l}\text { Sad/Depressed/ } \\
\text { Discouraged (5) }\end{array}$ & Frustrated (4) & $\begin{array}{l}\text { Exhausted/ } \\
\text { Weary (4) }\end{array}$ \\
\hline \multicolumn{5}{|l|}{ Males } \\
\hline $\begin{array}{l}\text { Race/Ethnicity } \\
\text { European American } \\
\begin{array}{l}n=2 \\
(X=1)\end{array}\end{array}$ & Conflicted (1) & Constricted (1) & & \\
\hline $\begin{array}{l}\text { MOC } \\
\qquad \begin{array}{l}n=7 \\
(X=3.71)\end{array}\end{array}$ & $\begin{array}{l}\text { Frustrated/ } \\
\text { Disappointed (5) }\end{array}$ & Angry (4) & $\begin{array}{l}\text { Defensive/ } \\
\text { Marginalized (3) }\end{array}$ & $\begin{array}{l}\text { Excited/ } \\
\text { Hopeful (2) }\end{array}$ \\
\hline
\end{tabular}

MOC, men of color; WOC, women of color.

those words and the ranking for each cluster, comparing instructors of color by gender to white Euro-American males and females. We illustrate these intersections of the diversity labor market with these emotional tags in order to prompt discussions of potential micropolicy responses to the diversity education movement in higher education.

In the interview process we artificially restricted our participant-instructors to the list of five words to describe their emotional responses to teaching required diversity education courses. The first intersection of patterns occurs in contrasting the overall density of words used to describe emotional responses when serving as the instructor of record for a required diversity course. White males $(n=2)$ used only two words between them: conflicted and constricted. One white male instructor declined to provide any listing, citing explicitly that there is "no emotional dimension" to teaching his courses.

In contrast, women of color $(n=7)$ used an average of 4.63 words from their five-word allocation, the highest of any group. Men of color $(n=7)$ used almost one full word less, with 3.71 words on average. No racial/ethnic differences were discerned in the average word count to describe emotions across these groups; Ed (African American male) alone used only two words; Dadisi (African American), and José (Latino/Chicano) used three words and the remaining four men of color all used four or five words. Similarly, among all women, word usage ranged from as few as two (a white woman) or three words (including white and African American women), while female instructors from each of the four racial/ethnic groups used the full five words.

We emphasize this range of word usage to track two patterns, within and between genders and race/ethnicities. Our two white male instructors cited little or no emotion- 
ality in their teaching, even when interrogated on this dimension directly by the interviewers. White women, women of color, and men of color showed a richer density of emotional responses, suggesting that these three groups of instructors share both an additional instructional burden and an additional resource for their students.

Stereotypes for gender role expectations would suggest restricted emotional responses by male instructors, but these stereotypes are subverted by the racial/ethnic divide. White males do state a restricted range of emotional responses to their classroom teaching. By enacting instructional roles within the diversity classroom that include emotionality, men of color may be particularly challenged in student evaluations, and this may conflict with their stated preferences for teaching as a neutral authority (cf. Perry et al. 2006). For women of color, the challenge may lie not in their articulation of emotional dimensions, but in the comparative drain of those emotions in contrast to white women and white men.

We next examine the meaning of these word clusters, beginning again with the notation that white male instructors describe little or no emotional terminology with regards to their teaching when directly requested. We let the words "conflicted" and "constricted" stand as representative of their articulated range of emotional responses.

The emotional terminology employed by women and men of color clusters primarily around dimensions of anger (ranked second for men and first for women of color). Interestingly, men of color used just the single word "anger" in all four instances. All seven women of color provided words from a similar cluster, but with a wider range of terms: anger, resentment, and rage. This suggests a depth of anger associated with teaching diversity courses for both men and women of color that is not isolated or idiosyncratic. The target of this anger or rage is not clarified, but could certainly include their students in the classroom, their positionality within diversity classrooms, and their administrators of a campus who create this segmented labor market without attention to its latent effects. In other analyses, we found that instructors expressed this anger primarily in response to their devalued positions and identities (Perry et al. 2008). This combination of extra work and devaluation is toxic and characteristic of secondary academic markets.

White women instructors express frustration and exasperation most often in their emotional reflections, and in this they are most similar to the men of color, for whom words of frustration and disappointment also dominated. Men of color cluster their emotional terminology first by emphasizing frustration, next anger (ranked second) and then words such as "defensive" and "marginalized" (ranked third).

White women instructors shift their second cluster to words of joy, delight, and empowerment, showing a rich and deep attachment to these emotions across instructors. Eight of the ten white women instructors used terms such as: excited, elated, joy, bliss, or delight at least once in their five responses. Three of the ten white women instructors also claimed the emotion of empowerment, while only one woman of color did so. However, three of seven women of color did use a term of joy, happiness, or excitement once in a reflection (each word expressed only once across all seven women) and three men of color shared the words hope or excitement to describe their teaching. 
In contrasting these racialized experiences across gender, the burden of teaching diversity is distinctive for women of color and their male colleagues when compared to white (mostly female) colleagues. This reflects an invisible dimension of race privilege in the academy associated with the teaching role for whites of any gender. For white women, their joy is tempered by their stress, insecurity, fear, and intimidation associated with teaching these courses (ranked fourth). This leaves a balance that is weighted toward more difficult emotional tasks in the classroom when compared to their white male peers.

Finally, we highlight that women of color instructors round out their primary reflections with discouragement, sadness, depression (ranked second), frustration (ranked third), and exhaustion and weariness (ranked fourth) as their key reflected themes. Despite isolated statements of joy or excitement, this pedagogical work is burdensome in both its material conditions (overrepresentation of instructors of color in general, extra time spent on legitimating classroom scholarship and authority) and in its emotional characterization. Aguirre concludes the academic workplace is often perceived as a "place of enlightened thought and discourse" that will be "free of conflict and stress" (2000:2). In contrast, he argues the reality of the heavy burden of teaching and service responsibilities placed on women and minorities as they "perform institutional roles that allow higher education to pursue diversity on campus" (2002:3).

\section{Discussion and Policy}

The words of these instructors on a Research I campus illustrate a split academic labor market in which emotional work is a primary marker of gender and racial differences in the experiences of teaching. White males are scarce within this secondary market of diversity instruction, but they tell a story of detached professionalism and emotionally distinctive practice in presenting what they deem uncontested knowledge.

The first dimension of a split labor market is linked to distorted, devalued workloads in teaching. We have evidence of diversity course "dumping" that excludes systematically the nonminority assistant and associate professors from this academic duty. Among all Full Professors, the two white males represented comprise a miniscule proportion of an available labor pool. Today, in the contexts of new racism (Bonilla-Silva et al. 2004) and new racial politics, we can propose a splitting of academic labor markets by race/ class and gender through subtle dynamics of differential access to resources and teaching schedules. Structurally limited opportunities for advancement are reflected in these unequal burdens and privileges.

The second dimension of a devalued secondary market within a Research I institution is the distinctive emotional burden of teaching these course for men and women of color who express anger and rage toward multiple layers of devaluing their credibility, authority, and scholarly integrity. These emotions are balanced for women of color with muted expressions of empowerment and happiness linked through this teaching. Men of color find little to balance their anger and frustration. For white women, especially for Full Professors, the balance with joy, elation, and excitement in the classroom is more robust, and 
the experience of frustration and anger is stated as secondary. These instructors' words serve to break the "conspiracy of silence" (Turner 2002:86) around contested sectors of internal academic labor markets. Using lenses of critical race theory (Aguirre 2000; BonillaSilva et al. 2004) and antiracist feminism (Mirchandi 2003), the layering of race/class and gender within academic organizations and in the diversity classroom is thick with potential for understanding ongoing national and local problems of retention and academic labor markets.

These split labor market dynamics are likely exacerbated by the material conditions of "joint appointments" and "opportunity hires," whether at a Research I institution or on a liberal arts undergraduate campus. When these intersect with student enrollment growth in mandated diversity courses, we should question the patterns of classroom assignments and the consequences for academic workers. Within the new forms of academic privilege, we may systematically assign individuals to "bad" contexts (Rosenblum and Rosenblum 1996) as a latent effect of our general education goals and opportunity hires.

As sociologists we have the tools, the frameworks, and the theoretical lenses, but too often lack self-reflection on how protecting time and privileges, small though they may seem, disadvantage others. Sociology departments and our discipline are confronted with assessing these key elements of new labor markets and new curricula in this $21^{\text {st }}$ century.

From a practical standpoint, we know that academic careers require major investments of mentorship, department resources, and postdoctoral training; these challenges for instructors of color are a challenge for all of us. The University of Washington Bradford Report suggests:

A critical aspect of organizational change is training for all faculty about issues faced by new faculty, especially faculty of color. Such training might address norms of collegiality and mentoring, ways to evaluate scholarship in new fields, and how to assess student teaching evaluations of faculty of color. Deans and chairs have a critical leadership role to motivate all faculty to participate in efforts of institutional change. (Bradford Report 1997)

The National Science Foundation is offering large carrots in making organization changes through ADVANCE grants for campuses. Their goal is to develop systemic approaches to increase the representation and advancement of women in academic science and engineering careers to develop a more diverse science and engineering workforce. Creative local strategies to realize this goal are still sought (NSF 2008).We can bring labor market theories to this analysis as a way to interrogate individual, organizational, and segmented academic disciplines, and the normative structures that may influence pipelines at the national level.

\section{Policies in the Minefield}

It is ironic that the APA wrote their survival guide for women and minorities to emphasize "strategies to support members of underrepresented groups as they encounter 
emotional and strategic challenges that may occur if they are denied tenure or promotion" (APA 2004). This omits the ongoing emotional challenges of marginalized teaching, service and research that may be encountered during pre-tenure years or graduate school. It also distorts post-tenure service to diversity education that may continue throughout the career, as it does for one-third of our minority Full Professors. Continued diversity instruction may be a choice, or a habit of assignment, but it carries a differential burden by race/ethnicity at every instructional rank. Below, we consider the implications for policies at the campus level.

In Jacobs's (2004) research on the faculty time divide, he recommends that all types of campuses should change their academic structures: "We should place on the agenda the notion not simply of tinkering with the tenure clock but fundamentally altering the expectations of the academic calling" (p. 25). Attaching diversity teaching to the job conditions of secondary labor markets may structurally limit opportunities for career survival and advancement. We can begin by assessing the academic privileges that affect our emotional understandings of job satisfaction and examine the distortion of diversity structures in the academy. These privileges include our access to time and resources to develop our scholarship and pedagogy, decision making in the curriculum and control over our dayto-day schedules, and the ability to generate an enriching work setting. Distortions imbedded in the organization of research, teaching, and service are passed on by dominant faculty members. Policies to address these might include:

1. Reconfigure diversity instructor assignments. Because of the emotional "tax" of diversity courses, we should introduce a principle of rotation into the curriculum at the organizational level. Diversity and inequality topics can be taught through the perspectives of any specialization within the discipline of sociology, and no instructor should be exempt from this labor market. This opens opportunities for minority faculty and graduate instructors to teach courses in their own specializations at developmentally appropriate times, and to reduce the burn out of emotional labor. We can examine the diversity of our labor market pools (in contrast to the bench sciences) and serve as models to the local campus. We can begin to research our successful market strategies for retention, and we should begin where faculty of diversity are now positioned. Research shows the cycle of recruitment and retention is layered from the department to the campus to the discipline (Allen 1997; Spalter Roth and Erskine 2007).

2. Resource instructors of color (and "others") who care enough to both teach and have major scholarly commitments within diversity dimensions. Support these dimensions of diversity scholarship - and expand beyond rewarding work that is published in "top tier" journals. Make time to systematically assess what our colleagues call Passionate Scholarship and Pedagogy (Perry et al. 2006). Reconnect our social activism to our teaching and research in ways that support diverse faculty agendas in social justice dimensions (hooks 1994).

3. Establish equity in placement principles. Make explicit the internal structures of labor markets across the academy and within disciplines. Identify where the valuation and evaluation of work is vague and will be reconstructed, and change who has the power to construct those meanings. Joint appointments should only be extended when the 
joining is mutual, well researched and we have evidence of cooperative agreements with positive histories of crosscutting activities and success among departments/ programs. Interdisciplinary efforts should not dangle by a single fragile thread of a minority faculty member's career, but instead build deep, thick understandings of academic diversity work in all its dimensions: scholarship, community needs, and curricular meanings.

4. Reconsider the instructional evaluation process. Remove or reduce the secondary labor market characteristic of ambiguous and potentially biased evaluation in this labor market sector. Gregory (2001) recommends transforming tenure and promotion criteria by expanding the definition of scholarly activity and placing more importance on teaching, service, and curriculum development activities. A thoroughgoing assessment of potential biases in evaluating teaching for diversity courses is one of our research goals (Bass et al. 2008), even when numbers are small and we are dependent upon qualitative inquiries. Departments and disciplines can review the journals they privilege in promotion and tenure, their "equations" for merit increases and annual evaluations, and the mentoring/support structures for those who toil, by choice or by default, in the diversity minefields of higher education.

Think about the dimensions of our current work as sociologists: writing a research grant proposal - nurturing a manuscript - collaborating in community projects - shepherding a student organization - revising a curriculum. Now imagine that assessment of the quality of our work will come primarily from a group that is (1) required to participate in your evaluation, (2) has no background in your subject, (3) has some antipathy toward your topic, (4) has little experience with your positionality in terms of race, class, gender, (5) by definition holds some stereotypic understanding or is ignorant of your topic (or why would they be here?), and (6) that this group will likely be the only evaluator of your work, and they will conduct this evaluation only after having 16 weeks to provide you with both nonverbal and verbal feedback on their best and worst days of the semester. Their summary comments will then be reviewed by tenured and fully promoted faculty members who have not labored in the same emotional minefield, who have little experience with this positionality, and whose access to research time and pedagogical assignments are largely protected by race or gender or seniority privileges of their academic labor market (APA 2004; Jacobs 2004).

Our commitment to a diverse discipline across all dimensions requires thoughtful approaches to the splits in the labor market that we create. What are the consequences of diversity curriculum requirements for recruiting and retention patterns in our discipline? How do these split our academic labor markets? The solution is not to segment (marginalize) diversity education, nor to remove instructors from chosen sites for their pedagogical and scholarly challenges. Rather, we should build from the ground up and the top down: we can develop supportive campus environments where diversity challenges are met by the entire faculty, without privileging some over others.

Labor market theories point us to key concepts of degraded labor, the role of academic administrators as employers and of privileged academics in maintaining their stratified positions; and the privileges of some faculty members in avoiding the diversity compo- 
nent of 21st-century higher education. Theories of intersectionality (Hill Collins 1990) help frame an understanding of the process by which racial/ethnic minority women and men are restricted from desirable jobs and assigned to less attractive ones through direct and indirect organizational means (Feagin and Eckberg 1980). The visibility of these vertical, horizontal, and internal markets may be veiled by the academic positionality of dominant group members because "One privilege of the privileged is not to see their privilege" (McIntosh 1989). Future research efforts on our part will focus on the connections of these labor market sectors of diversity education with the academic job satisfaction of our participant-instructors. Given the national data and disciplinary reports on low retention rates for faculty of color, we encourage further policy analysis to assess and remedy these market splits in the academy.

\section{Acknowledgments}

We thank Julia McQuillan and Sheryl Grana for their thoughtful comments on an earlier draft, Grant Tietjen for his manuscript assistance, and three anonymous reviewers from The Sociological Quarterly. Our greatest debt and gratitude to our colleagues who participated in this research. Research support was provided by the University of NebraskaLincoln Sociology Graduate Student Research Award. This address was originally presented at the Midwest Sociological Society annual conference in St. Louis, Missouri, on March 28, 2008.

\section{Note}

${ }^{1}$ Sixteen of the original instructors were unavailable for interviews because of retirement, lack of faculty retention, two deaths or loss of contact information after graduating from or leaving their doctoral program.

\section{References}

Acker, Joan. 1999. "Rewriting Class, Race and Gender: Problems in Feminist Thinking." Pp. 44-69 in Revisioning Gender, edited by M. Ferree, J. Lorber, and B. Hess. Newbury Park, CA: Sage.

—. 2006. "Inequality Regimes: Gender, Class and Race in Organizations." Gender E Society 20:441-64.

Aguirre, Adalberto, Jr. 2000. “Academic Storytelling: A Critical Race Theory Story of Affirmative Action." Sociological Perspectives 43:319-39.

Allen, Henry L. 1997. "Faculty Workload and Productivity: Gender and Ethnic Disparities." NEA Almanac of Higher Education 25-47.

American Association of Colleges and Universities (AACU). 2000. "National Survey Finds Diversity Requirements Common around the Country." Accessed July 2003; http:// www.diversityweb.org/Digest/F00/survey.html 
American Association of University Professors. 2004. Contingent Faculty and the New Academic Labor System. Washington, DC: American Association of University Professors.

Anderson, Judith and Melissa Swazey. 1998. "Reflections on the Graduate Student Experience: An Overview." New Directions for Higher Education 101:3-13.

Antonio, Anthony Lising. 2002. "Faculty of Color Reconsidered: Reassessing Contributions to Scholarship." The Journal of Higher Education 73:582-602.

APA Committee on Women in Psychology and APA Commission on Ethnic Minority Recruitment, Retention, and Training in Psychology. 2004. "Surviving and Thriving in Academics." Accessed January 2008; http://www.apa.org/pi/oema/surviving/ homepage.html

Baca Zinn, Maxine and Bonnie Thornton Dill. 1994. "Difference and Domination" in Women of Color in U.S. Society. Philadelphia, PA: Temple University.

—. 1996. "Theorizing Difference from Multiracial Feminism." Feminist Studies 22:321-31.

Baron, Harold. 1975. "Racial Domination in Advanced Capitalism." Pp. 173-216 in Segmented Work, Divided Labor, edited by R. Edwards, R. Reich, and D. Gordon. Cambridge, MA: Harvard University Press.

Barrera, Mario. 1979. Race and Class in the Southwest: A Theory of Racial Inequality. West Lafayette, IN: Notre Dame University Press.

Bass, Katie, Devan Crawford, April Schueths, and Tanya Gladney. 2008. "Mixed Messages in Teaching Diversity: A Mixed-Methods Assessment." Paper presented at the Midwest Sociological Society Meetings, April, St. Louis, MO.

Bell, Sandra, Marina Morrow, and Enagelia Tatsogluol. 1999. “Teaching in Environments of Resistance: Toward a Critical, Feminist and Antiracist Pedagogy." Pp. 23-48 in Meeting the Challenge, edited by M. Mayberry and E. Rose. New York: Routledge.

Bellas, Marcia. 1994. "Comparable Worth in Academia: The Effects on Faculty Salaries of the Sex Composition and Labor-Market Conditions of Academic Disciplines." American Sociological Review 59:807-21.

—. 1999. "Emotional Labor in Academia: The Case of Professors." Annals of the American Academy of Political and Social Science 561:96-111.

Bellas, Marcia, P. Neal Ritchey, and Penelope Parmer. 2001.“Gender Differences in the Salaries and Salary Growth of University Faculty." Sociological Perspectives 44:163-87.

Bird, Sharon, Jacquelyn S. Litt, and Yong Wang. 2004. "Creating Status of Women Reports: Institutional Housekeeping as 'Women's Work.' " NWSA Journal 16:194-206.

Blackwell, James. 1988. "Faculty Issues: The Impact on Minorities." Review of Higher Education 11:417-34.

Blau, Peter M. 1973. The Organization of Academic Work. New York: Wiley.

Blauner, Robert. 1972. Racial Oppression in America. New York: Harper \& Row.

Bonacich, Edna. 1972. "A Theory of Ethnic Antagonism: The Split Labor Market." American Sociological Review 37:547-59.

Bonilla-Silva, Eduardo, Amanda Lewis, and David G. Embrick. 2004. " 'I Did Not Get That Job because of a Black Man': The Stories and Testimonies of Color-Blind Racism." Sociological Forum 19:555-81. 
Bradford Report. 1997. "Report of Minority Faculty Recruitment and Retention." Accessed January 2010; http://www.washington.edu/provost/ap/eoaa/aa_bradford report.html

Britton, Dana and Laura Logan. 2008. "Gendered Organizations: Progress and Prospects." Sociology Compass 2:107-21.

Browne, Irene and Joya Misra. 2003. "The Intersection of Gender and Race in the Labor Market." Annual Review of Sociology 29:487-513.

Creswell, John. 1998. Qualitative Inquiry and Research Design. Newbury Park, CA: Sage.

Doeringer, Peter B. and Michael J. Piore. 1971. Internal Labor Markets and Manpower Analysis. London, UK: Heath.

Exum, William. 1983. "Climbing the Crystal Stair: Values, Affirmative Action, and Minority Faculty." Social Problems 30:383-99.

Feagin, Joe R. and Douglas Lee Eckberg. 1980. “Discrimination: Motivation, Action, Effects, and Context." Annual Review of Sociology 6:1-20.

Gallos, Joan V., V. Jean Ramsey, and Associates. 1997. Teaching Diversity: Listening to the Soul, Speaking from the Heart. Hoboken, NJ: Jossey-Bass.

Gordon, David, Richard Edwards, and Richard Reich. 1982. Segmented Work, Divided Workers. New York: Cambridge University Press.

Gregory, Sheila T. 2001. "Black Faculty Women in the Academy: History, Status, and Future." The Journal of Negro Education 70:124-38.

Harlow, Roxanna. 2003. “'Race Doesn't Matter, But . . .': The Effect of Race on Professors' Experiences and Emotion Management in the Undergraduate College Classroom." Social Psychology Quarterly 66:348-63.

Hill Collins, Patricia. 1990. Black Feminist Thought. New York: Routledge.

Hochschild, Arlie Russell. 1979. "Emotion Work, Feeling Rules, and Social Structure." American Journal of Sociology 85(3):551-75.

- 1983. The Managed Heart: Commercialization of Human Feeling. Berkeley: University of California Press.

hooks, bell. 1994. Teaching to Transgress: Education as the Practice of Freedom. New York: Routledge.

Ivey, Elizabeth. 2005. "Gender Differences among Contingent Faculty." Accessed January 2010; http://www.awis.org/pubs/sloanreport.pdf

Jacobs, Jerry. 2004. "The Faculty Time Divide." Sociological Forum 9:3-27.

Jimoh, A. Yemisi and Charlene Johnson. 2002. "Racing into the Academy: Pedagogy and Black Faculty." Pp. 286-98 in Race in the College Classroom: Pedagogy and Politics, edited by B. Tusmith and M. T. Reddy. New Brunswick, NJ: Rutgers University Press.

Kalleberg, Arne and Aage Sorensen. 1998. "The Sociology of Labor Markets." Annual Review of Sociology 35:207-29.

Karabel, Jerome. 2004. The Chosen. Boston, MA: Houghton Mifflin.

Kolodny, Annette. 1980. "Dancing through the Minefield: Some Observations on the Theory, Practice and Politics of a Feminist Literary Criticism.” Feminist Studies 6:1-25. 
Kulis, Stephen and Heather E. Shaw. 1996. "Racial Segregation among Postsecondary Workers." Social Forces 75:575-91.

—. 1997. "Gender Segregation among College and University Employees." Sociology of Education 70:151-73.

McBrier, Debra Branch. 2003. "Gender and Career Dynamics within a Segmented Professional Labor Market." Social Forces 81:1201-66.

McCluskey, Erin. 2004. "Ethnicity, Race Affects Student Learning." Iowa State Daily, December 1,p. 6.

McIntosh, Peggy. 1989. "White Privilege: Unpacking the Invisible Backpack." Peace and Freedom. 10-12.

Menges, Robert and William Exum. 1983. "Barriers to the Progress of Women and Minority Faculty." Journal of Higher Education 54:123-43.

Mirchandi, Kiran. 2003. "Challenging Racial Silences in Studies of Emotion Work: Contributions from Anti-Racist Feminist Theory." Organization Studies 24:721-42.

National Science Foundation. 2008. "ADVANCE Grant." Accessed March 3, 2010; http:// www.nsf.gov/funding/pgm_summ.jsp?pims_id=5383

Paludi, Michelle, ed. 1990. Ivory Power. Albany: State University of New York Press.

Perry, Gary, Helen Moore, Katherine Acosta, and Crystal Edwards. 2006. “Dialogue on Diversity Teaching: Reflections on Research, Pedagogy, and Passion for Social Justice." Pp. 51-65 in Challenges of Multicultural Education, edited by N. P. Davis and J. Schultz. Boulder, CO: Paradigm.

Perry, Gary, Helen Moore, Kathy Acosta, Connie Frey, and Crystal Edwards. 2009. “Maintaining Credibility and Authority as an Instructor of Color in Diversity-Education Classrooms: A Qualitative Inquiry." Journal of Higher Education 80:80-105.

Pratt, Linda Ray. 1997. “Disposable Faculty: Part-Time Exploitation as Management Strategy." Pp. 264-77 in Will Teach for Food, edited by C. Nelson. Minneapolis: University of Minneapolis Press.

Reinharz, Shulamit. 1992. Feminist Methods in Social Research. New York: Oxford University Press.

Renzulli, Linda, Linda Grant, and Sheetija Kathuria. 2006. "Gender, and the Wage Gap: Comparing Faculty Salaries in Predominately White and Historically Black Colleges and Universities." Gender \& Society 20:491-510.

Reskin, Barbara and Patricia Roos. 1991. Job Queues, Gender Queues. Philadelphia, PA: Temple University.

Risman, Barbara. 2004. "Gender as a Social Structure: Theory Wrestling with Activism." Gender \& Society 18:429-50.

Roemer, Robert E. and James E. Schnitz. 1982. “Academic Employment as Day Labor: The Dual Labor Market in Higher Education." The Journal of Higher Education 53:514-31.

Rosenblum, Gerald and Barbara Rubin Rosenblum. 1996. "The Flow of Instructors through the Segmented Labor Markets of Academe." Higher Education 31:429-45.

Rosenfeld, Rachel A. 1981. “Academic Men's and Women's Careers." Social Science Research 10:337-63. 
Sleeter, Christine E. 1996. "Multicultural Education as a Social Movement." Theory into Practice 35:239-347.

Sleeter, Christine and Jamy Stillman. 2005. "Standardizing Knowledge in a Multicultural Society." Curriculum Inquiry 35:27-46.

Smith, Vicki. 1997. "New Forms of Work Organization." Annual Review of Sociology 23:315-39.

Spalter Roth, Roberta and William Erskine. 2007. "Race and Ethnicity in the Sociology Pipeline." Retrieved January 2010; http://www.asanet.org/galleries/default-file/Minorities_Career_Pipeline.pdf

Steinberg, Ronnie J. and Deborah M. Figart. 1999. “Emotional Labour since The Managed Heart." Annals of the American Academy of Political and Social Science 56:8-26.

Trower, Cathy. 2002. "Why So Few Minority Faculty and What to Do? Diversifying the Region's Professoriate." Connection: New England's Journal of Higher Education 17:25-27.

Turner, Caroline Sotello Viernes. 2002. "Women of Color in Academe: Living with Multiple Marginality." Journal of Higher Education 73:74-93.

Turner, Caroline S. V. and S. Meyers Jr. 2000. Faculty of Color in Academe: Bittersweet Success. Boston, MA: Allyn \& Bacon.

Vargas, Lucila. 1999.“When the 'Other' Is the Teacher: Implications of Teacher Diversity in Higher Education.” The Urban Review 31:359-83.

—. 2002. Women Faculty of Color in the White Classroom. New York: Peter Lang. 